\title{
Zielona infrastruktura wyzwaniem dla logistyki miejskiej
}

http://dx.doi.org/10.18778/8142-085-3.14

\author{
Monika Janasz, Patryk Kałużyński \\ Katedra Logistyki, Wydział Ekonomiczno-Socjologiczny \\ Uniwersytet Łódzki
}

\section{Wstęp}

W ostatnich latach nasila się występowanie skrajnych warunków pogodowych, takich jak ekstremalnie wysokie temperatury, susze czy ulewne deszcze, do tego dokłada się postępujący proces urbanizacji i wyjątkowo szybki rozwój infrastruktury na coraz większych obszarach terenów miejskich. Czynniki te wymuszają na nas zastosowanie nowego podejścia do zagospodarowania istniejących już zasobów naturalnych oraz wytworzenia nowych obszarów z przeznaczeniem dla zieleni miejskiej.

Celem artykułu jest uświadomienie odbiorcom przyczyn występowania coraz bardziej skrajnych zjawisk pogodowych na przestrzeni miejskiej oraz przedstawienie sposobów walki z tymi zjawiskami przy jednoczesnych staraniach o zwiększenie komfortu życia mieszkańców.

\section{Błękitno-zielona sieć ze szczególnym uwzględnieniem Aglomeracji Łódzkiej}

Wystąpienie ekstremalnych warunków pogodowych na przestrzeni ostatnich kilku lat pozwoliło zaobserwować, że w Łodzi stosowane są nieelastyczne systemy zagospodarowania wody deszczowej przy wszechobecnej szczelnej „betonowej płycie”. Te stosowane okazują się nieużyteczne i nieefektywne. Jednocześnie rosną oczekiwania mieszkańców co do dostępności naturalnej przestrzeni publicznej, jej jakości oraz estetyki. Naprzeciw tym problemom oraz wymogom stara się wyjść projekt błękitno-zielonej sieci (Wagner, Krauze, Zalewski, 2013). 
Pojęcie błękitno-zielonej sieci nieodzownie wiąże się z usługami ekosystemów, czyli korzyściami, jakie gospodarstwa domowe, gospodarka oraz społeczność osiągają dzięki środowisku naturalnemu. Kapitał przyrodniczy staje się zasobem generującym usługi ekosystemów będące strumieniem korzyści.

Istnieje silny związek między usługami oferowanymi przez ekosystemy a obecnym oczekiwaniem wysokiej jakości życia. Strumień korzyści, jakie oferuje nam środowisko naturalne, został przedstawiony w tabeli $1^{1}$.

Tabela 1. Korzyści usług ekosystemów

\begin{tabular}{|c|c|}
\hline Rodzaj usług & Korzyści \\
\hline Siedliskowe & $\begin{array}{l}\text { - tworzenie gleby } \\
\text { - fotosynteza i produkcja pierwotna } \\
\text { - cykl hydrologiczny } \\
\text { - cykl biogeochemiczny (obieg azotu, węgla, siarki, fosforu i innych) }\end{array}$ \\
\hline Zaopatrujące & $\begin{array}{l}\text { - żywność (produkty zwierzęce, roślinne) } \\
\text { - woda } \\
\text { - leki } \\
\text { - materiały trwałe (drewno, włókna) } \\
\text { - produkty przemysłowe (tłuszcze, oleje, barwniki) } \\
\text { - paliwa } \\
\text { - wzory do stworzenia analogicznych substancji syntetycznych } \\
\text { - zasoby genetyczne }\end{array}$ \\
\hline Kulturowe & $\begin{array}{l}\text { - rekreacja, turystyka, funkcja estetyczna } \\
\text { - funkcja edukacyjna } \\
\text { - inspiracje kulturowe, duchowe i intelektualne } \\
\text { - funkcja relaksacyjna } \\
\text { - relacje społeczne }\end{array}$ \\
\hline Regulacyjne & $\begin{array}{l}\text { - regulacja klimatu } \\
\text { - neutralizacja i rozkład opadu } \\
\text { - oczyszczanie gleb, powietrza, wód } \\
\text { - kontrola erozji } \\
\text { - procesy przenoszenia (zapylanie roślin) } \\
\text { - ochrona przed promieniowaniem UV } \\
\text { - kontrola rozprzestrzeniania się bakterii i drobnoustrojów } \\
\text { - tagodzenie ekstremalnych warunków pogodowych }\end{array}$ \\
\hline
\end{tabular}

Źródło: opracowanie własne na podstawie Millennium Ecosystem Assessment, 2005.

Zmiany klimatu jesteśmy w stanie prognozować obecnie w perspektywie 3040 lat, natomiast struktura miast i obszarów zurbanizowanych to zazwyczaj zabu-

1 J. Gorgoń, Znaczenie i rola błękitno-zielonej infrastruktury w adaptacji do zmian klimatu, http://www.ietu.katowice.pl/aktual/Poleko2016/4_Gorgon_J_Znaczenie_i_rola_BZI_w_ adaptacji_do_zmian_klimatu_zab.pdf [dostęp 20.04.2017]. 
dowa z przeznaczeniem użytkowym na 30-100 lat. Historia dostarcza nam jednak wielu przykładów o wiele dłuższego wykorzystywania tworzonej przez ludzi zabudowy $^{2}$. Ta relacja czasowa sprawia, że polityka miejska związana z adaptacją obszarów miejskich do znaczących zmian pogodowych stanowi coraz większe wyzwanie i wymusza ich uwzględnienie (Millennium Ecosystem Assessment, 2005).

Łódź jako miasto znajdujące się na granicy wododziału rzek Odry i Wisły, posiadające wiele drobnych cieków i aż 18 małych rzek w granicach administracyjnych, stanowi idealny obszar do korzystania z usług ekosystemów w pełni ich wydajności (Woźniak, 2012). Jednak ciągły rozwój infrastruktury oraz znaczna przebudowa w ostatnich latach sprawiają, że brakuje miejsca na obszary naturalne. Dopiero w roku 2010 powstała koncepcja zagospodarowania naturalnych terenów na obszarach miejskich i podmiejskich o nazwie „Błękitno-Zielona Łódź”. Wykorzystywać ma ona zachowany w dobrym stanie oraz zrewitalizowany system rzek, ich dolin oraz przynależących do nich obszarów zielonych. Powstanie tej sieci ma na celu podtrzymanie ciągłości procesów ekologicznych oraz wsparcie usług ekosystemowych w mieście ${ }^{3}$.

Najważniejszymi z usług ekosystemów, jakie w Łodzi zostały uwzględnione, są neutralizacja i rozkład opadu, oczyszczanie powietrza oraz łagodzenie ekstremalnych warunków pogodowych. Wykorzystanie potencjału środowiska naturalnego pozwala na ograniczenie kapitału wykorzystywanego do łagodzenia negatywnych skutków pogody, takich jak:

- podtopienia i powodzie,

- wystąpienie zjawiska miejskiej wyspy ciepła.

Zjawisko miejskiej wyspy ciepła polega na występowaniu wysokiej temperatury powietrza w obszarze wysoko zurbanizowanym (zob. ilustr. 1). Niedostatek obszarów zielonych i szczelna betonowa pokrywa miasta ograniczają zachodzenie takich procesów, jak infiltracja (proces wsiąkania wody w glebę), intercepcja (zatrzymanie wody na powierzchni roślin) oraz ewapotranspiracja (parowanie wody z roślin), które w znaczącym stopniu przyczyniają się do obniżenia temperatury na obszarach ich występowania ${ }^{4}$.

Przeciwdziałanie podtopieniom oraz powodziom wiąże się jednak ze zmianą spojrzenia na rolę wody opadowej w mieście, a co za tym idzie zmianą nadal panującej filozofii odwadniania miasta na rzecz nawadniania go. Woda powinna przestać być zagrożeniem dla funkcjonowania miasta, a stać się elementem niezbędnym do jego prawidłowego funkcjonowania, przy zapewnieniu bezpieczeństwa podnoszącym jakość życia. Znajdowanie się na obszarze miejskim większej ilości wody wymaga jednak zapewnienia jej odpowiedniej przestrzeni w okresach

\footnotetext{
2 Tamże.

3 M. Singer, Projekt „Błłękitno-Zielona Łódź”, http://www.uni-logistics.uni.lodz.pl/pliki/Artykul_ Singer_Malgorzata_Blekitno-zielona_Lodz.pdf [dostęp 20.04.2017].

4 Tamże, s. 3.
} 
nasilonych opadów, tj. większych terenów parków, miejsc rekreacyjnych, rozlewisk i zbiorników mogących przyjąć dodatkową objętość retencyjną.

\section{Wyspa ciepla nad miastem - przykładowy rozklad temperatury}

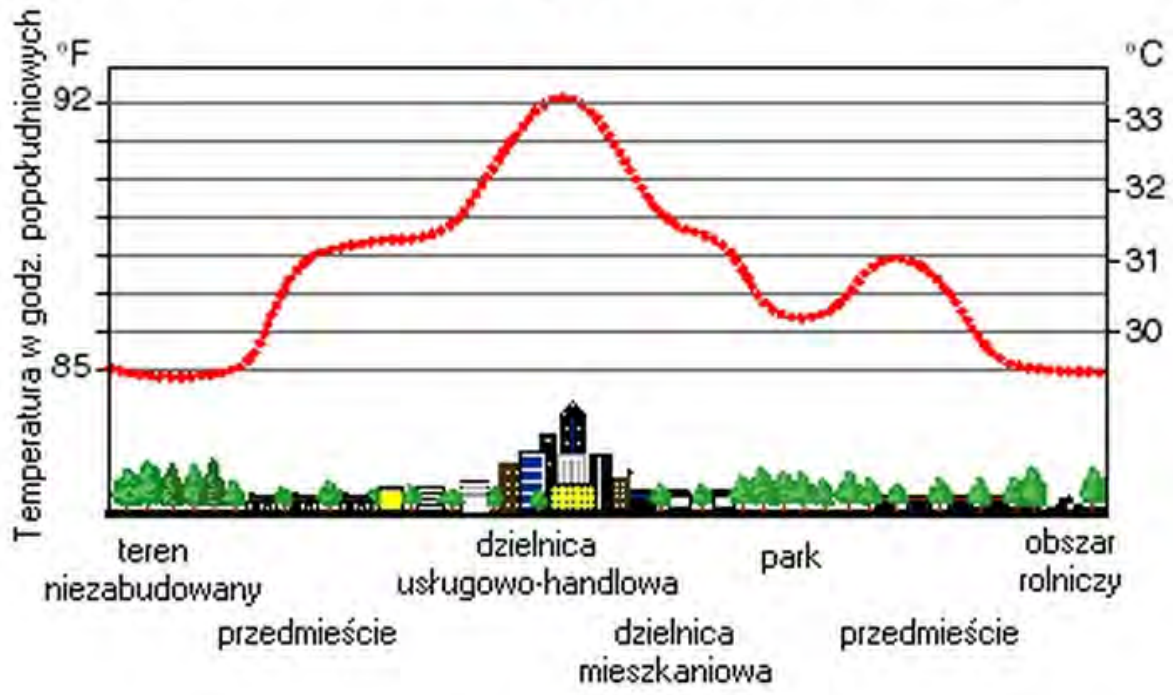

Ilustracja 1. Miejska wyspa ciepła

Źródto: Miejska wyspa ciepła - jak powstaje i jak jej zaradzić, 2014, urbnews.pl.

Sama koncepcja błękitno-zielonej Łodzi w pierwszej kolejności stawia na właściwe inwestowanie w obszar miejski. Tworzenie, ochrona oraz odpowiednie wykorzystanie potencjału naturalnego stają się nadrzędnym celem rozwoju miasta. W dalszej kolejności należy brać pod uwagę konieczność zapobiegania i minimalizowania negatywnego wpływu, jaki wywierają przeprowadzane w mieście inwestycje na życie ludzi. W ostateczności dopiero rozważana jest kompensacja bądź naprawa negatywnego wpływu inwestycji na społeczeństwo lub środowisko. Prowadzenie inwestycji według tych zasad zostało przedstawione na ilustracji 2 (Wagner, Krauze, Jurczak, Zalewski, 2015).

Głównymi efektami wprowadzenia koncepcji błękitno-zielonej sieci w Łodzi są (Wagner, Krauze, Jurczak, Zalewski, 2015: 1):

- zapobieganie powodziom,

- oczyszczanie wód opadowych,

- poprawa mikroklimatu,

- złagodzenie zjawiska miejskiej wyspy ciepła,

- zmniejszenie zagrożenia chorobami alergicznymi i astmą. 


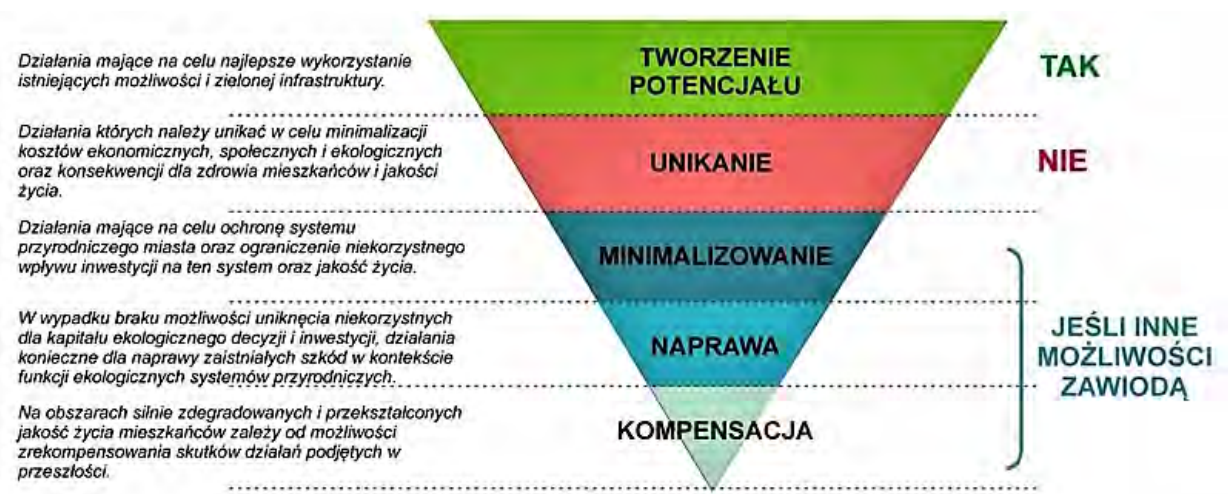

Ilustracja 2. Zasady prowadzenia inwestycji rozwojowych miast

Źródto: e-czytelnia.abrys.pl, Zielono-błękitna infrastruktura a retencja krajobrazowa w miastach, 2015.

Wprowadzenie koncepcji wymaga jednak dostępności czystej wody deszczowej w łódzkiej przestrzeni. Służyć temu ma opracowanie i wprowadzenie w życie wielu projektów konstrukcyjnych zwiększających retencję i wsiąkanie wód deszczowych oraz sedymentację i transformację zanieczyszczeń. Przykładem takiego projektu jest zrealizowany już plan rewitalizacji rzeki, doliny rzecznej oraz stworzenie parku miejskiego w dolinie Sokołówki. Wszystkie działania realizowane były w ramach projektu europejskiego SWITCH (Sustainable Water Manegement Improves Tommorow's Cities' Health). Ilustracja 3 przedstawia zakres prac oraz czasowy postęp w rewitalizacji doliny Sokołówki (Wagner, Krauze, Jurczak, Zalewski, 2015).

Kolejnym przykładem projektu wspierającego koncepcję błękitno-zielonej sieci jest ekohydrologiczna rekultywacja zbiorników wypoczynkowo-rekreacyjnych na zasilanej wodą deszczową rzece Bzurze w Arturówku. Zastosowane rozwiązania z zakresu biotechnologii ekosystemowych pozwalają na oczyszczanie i wydajną retencję wód deszczowych z terenów miasta zasilających rzekę oraz zbiorniki. Jednocześnie zastosowane rozwiązania pozwoliły na odtworzenie zróżnicowanego ekosystemu zbiorników (utworzenie pływających wysp, odtworzenie stref roślinności przybrzeżnej oraz zarybienie zbiorników). Ilustracja 4 przedstawia schemat działań rekultywacji dla rzeki Bzury i zbiorników rekreacyjnych w Arturówku.

Istnieje wiele rozwiązań o dużo mniejszej skali, które można zastosować w Łodzi, przy czym wiele $z$ nich wymaga gigantycznych nakładów finansowych. Tabela 2 przedstawia przykładowe rozwiązania wspierające koncepcję błękitno-zielonej sieci stosowane w Łodzi. 


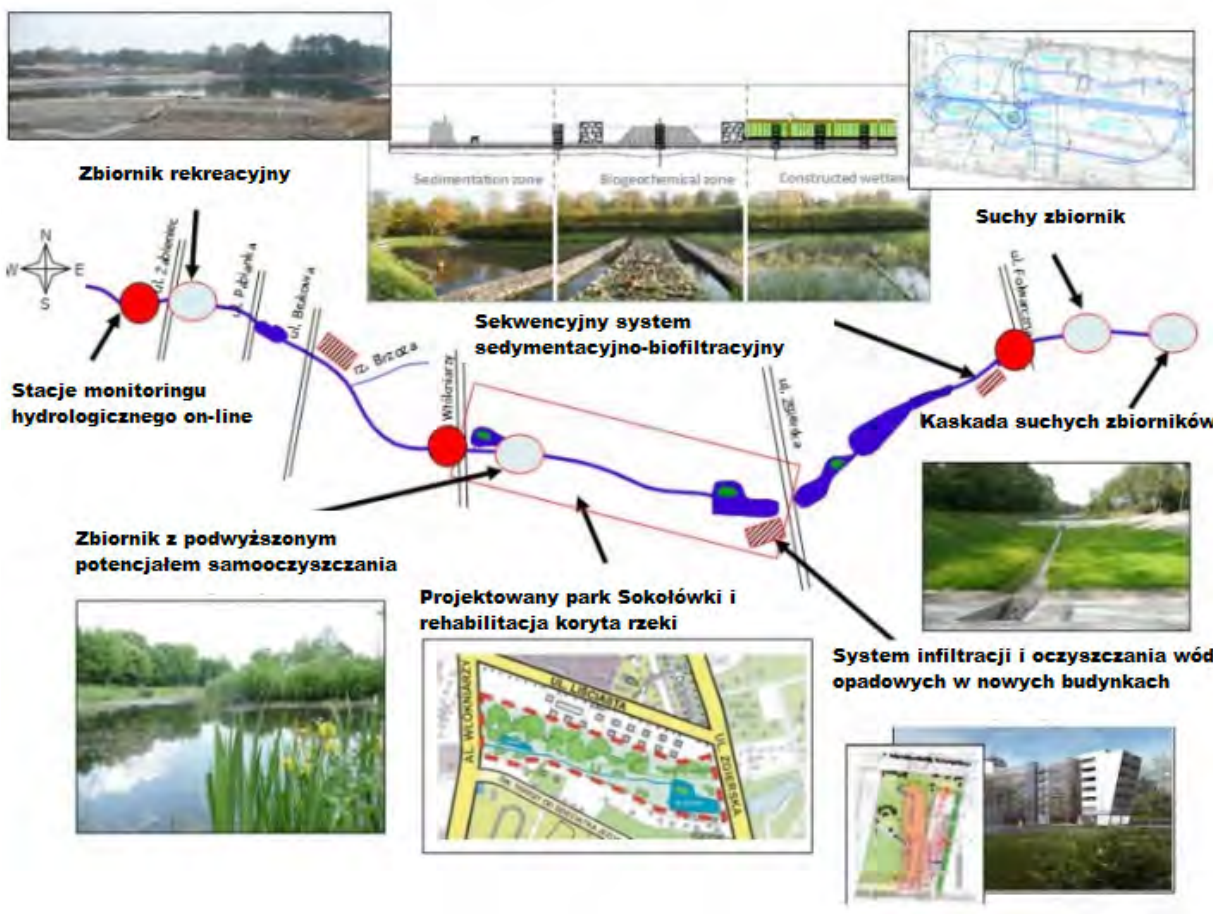

Ilustracja 3. Proces rewitalizacji doliny Sokołówki

Źródło: e-czytelnia.abrys.pl, Błękitno-zielona sieć, 2013.

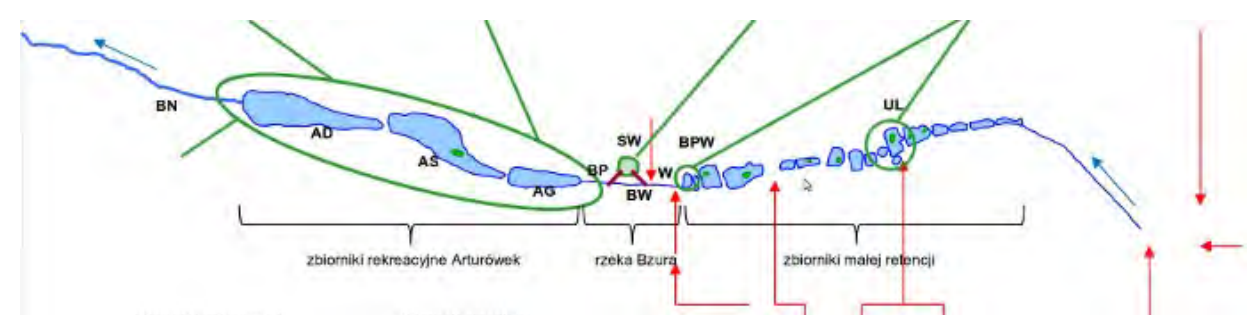

Objaśnienia:

$\leftarrow$ kierunek spływu wód deszczowych $<$ kierunek przepływu rzeki

BN - rzeka Bzura poniżej zbiorników Arturówek; AD - zbiornik Arturówek dolny; AŚ - zbiornik Arturówek środkowy; AG - zbiornik Arturówek górny; BP - rzeka Bzura powyżej zbiorników Arturówek; BW - rzeka Bzura poniżej ulicy Wycieczkowej; SW - staw przy ulicy Wycieczkowej; W - ulica Wycieczkowa; BPW - zbiornik nr 17 w kaskadzie powyżej ulicy Wycieczkowej; UL - zbiornik nr 7 w kaskadzie powyżej ulicy Wycieczkowej.

Ilustracja 4. System zbiorników wodnych w Arturówku na rzece Bzurze

Źródło: EHREK, Ekohydrologiczna rekultywacja zbiorników rekreacyjnych „Arturówek” jako modelowe podejście do rekultywacji zbiorników wodnych, http://www.arturowek.pl/content/ wdrozenia [dostęp 20.04.2017]. 
Tabela 2. Rozwiązania wpierające błękitno-zieloną sieć

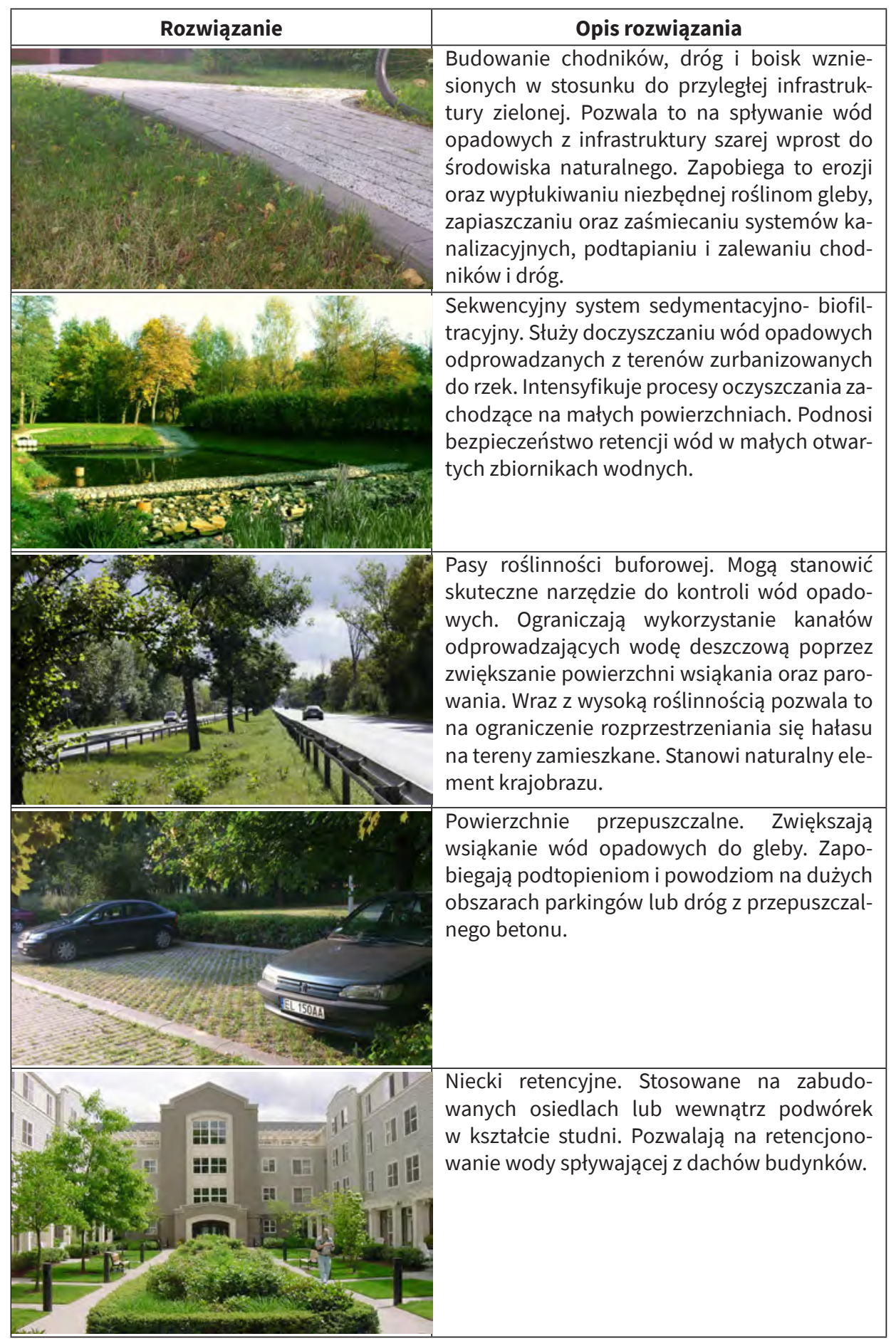

Źródło: opracowanie własne na podstawie Wagner, Krauze, Zalewski, 2013. 


\section{Zielone dachy, żyjące ściany jako przykład kreowania krajobrazu miejskiego}

Zielone budownictwo, w którego skład wchodzą zielone dachy oraz żyjące ściany, nie tylko posiada walor estetyczny, ale także pozwala na lepsze wykorzystanie ograniczonej przestrzeni miejskiej. Wkomponowanie zieleni w architekturę miejską daje możliwość zwiększenia jakości terenów zurbanizowanych poprzez częściową rekonstrukcję zieleni utraconej na rzecz budynków mieszkalnych, fabryk itp., wchodzących w skład przestrzeni miejskiej.

Wdrażanie nowych projektów i rozwiązań, ze szczególnym zwróceniem uwagi na ochronę środowiska naturalnego, coraz częściej stanowi wyzwanie dla władz miasta. Gęsta zabudowa terenu oraz wysoko rozwinięta sieć infrastruktury drogowej negatywnie wpływają na retencję wód opadowych, co w konsekwencji przyczynia się do powstania wielu problemów, takich jak powodzie, skażenie wód powierzchniowych czy zaburzenie równowagi w obiegu wody deszczowej ${ }^{5}$.

Innowacyjnym rozwiązaniem wpisującym się w koncepcję zrównoważonego rozwoju, stanowiącym częściowe rozwiązanie problemu małej retencji wody na terenach wysoko zurbanizowanych, są zielone dachy pokryte różnego rodzaju roślinnością. Istnieją dwa rodzaje zielonych dachów. Podział ten wynika z rodzaju, intensywności zazielenia oraz grubości podłoża. Pierwszy rodzaj to dachy intensywne, na których ze względu na grube podłoże, wynoszące od $20 \mathrm{~cm}$ do nawet 2-3 m, wysokości, zasadzona może być różnorodna roślinność, np. krzewy, trawa, drzewa itp., stąd często są one miejscami rekreacyjnymi. Ten typ dachu ze względu na zróżnicowaną roślinność wymaga dużych nakładów pracy związanych z pielęgnacją roślin. Drugi rodzaj zielonych dachów stanowią dachy ekstensywne, których podłoże jest cienkie, co ogranicza wybór zieleni, jaka może być na nich zastosowana. Warunki istniejące na tych dachach sprzyjają głównie rozwojowi różnego rodzaju traw, porostów oraz mchów. Stworzenie owych typów zielonych dachów możliwe jest jedynie na powierzchniach dachowych o płaskiej konstrukcji, których spadek wynosi 2-3\%. Wymogi te wynikają z faktu, że tego typu konstrukcje dachowe przynoszą najkorzystniejsze efekty, jeżeli chodzi o retencję wody deszczowej, oraz zapewniają równomierne nasłonecznienie, co w przypadku roślin jest istotne dla prawidłowego przebiegu fotosyntezy ${ }^{6}$.

Zielone dachy składają się z kilku warstw. Typowy układ warstwowy zielonego dachu przedstawia ilustracja 5 .

5 HYDROIDEA, Mała retencja wód w miastach. Zbiorniki retencyjne i zbiorniki infiltracyjnosedymentacyjne, http://www.hydroidea.com/oferta/mala_retencja_wody/[dostęp 20.04.2017].

6 wymarzony.ogród.pl, Zielone dachy. Sposób na roślinność w mieście i nie tylko, https:// www.wymarzonyogrod.pl/zakladanie-ogrodu/pomysly-na-ogrod/zielone-dachy-sposobna-roslinnosc-w-miescie-i-nie-tylko,23_1782.html; Zielony-Dach, Dach intensywny, ogrody dachowe, tarasy zielone, https://e-zielonydach.pl/dach-intensywny/ [dostęp 20.04.2017]. 


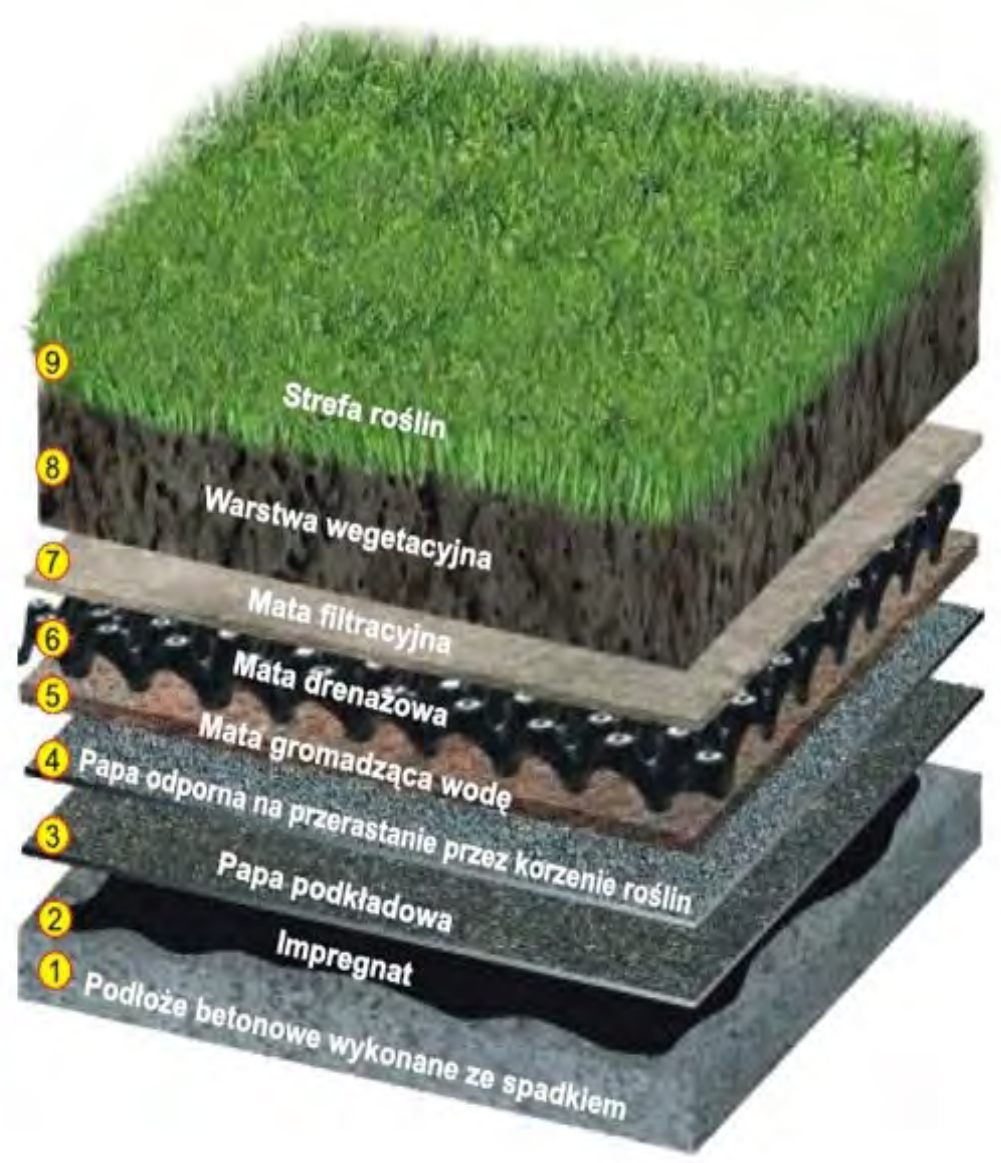

Ilustracja 5. Typowy układ wielowarstwowy zielonego dachu Źródło: http://www.obud.pl/art,5933,specjalna-papa-zgrzewalna-do-dachow-zielonych---izolmat-plan-zielony-dach-pye-pv250-s5,d_dachy [dostęp 20.04.2017].

Miastem, które kładzie nacisk na rozbudowę zieleni miejskiej poprzez zachowanie harmonii między budownictwem a florą, jest Hamburg. Polityka miasta skupia się na maksymalnym wykorzystaniu powierzchni dachowej pod zasiew różnego rodzaju zieleni. Aby przywrócić miastu niegdyś zniszczoną zieleń, do roku 2020 pod uprawę oraz zasiew różnorodnej roślinności ma zostać przeznaczona powierzchnia dachowa o łącznej wielkości 100 hektarów. Ponadto aby zachęcić inwestorów do wykorzystywania owego rozwiązania, miasto oferuje dofinansowanie w wysokości 60\% kosztów związanych z budową zielonego dachu. Niesie to korzyści zarówno dla miasta, jak i samego inwestora, który poprzez po- 
łączenie zielonego dachu z siecią kanalizacyjną może zredukować całkowite opłaty za wodę . Ponadto do zalet zielonych dachów należy zaliczyćs:

- zmniejszenie negatywnych skutków miejskiej wyspy ciepła (zwiększonej temperatury i niskiej wilgotności powietrza nad miastami),

- izolację budynków zarówno od wysokich, jak i niskich temperatur, co przekłada się na zwiększenie oszczędności energetycznych i finansowych,

- odciążenie kanalizacji dzięki częściowemu zatrzymaniu wody opadowej w glebie zielonych dachów, co dodatkowo zmniejsza ryzyko podtopień,

- poprawę jakości powietrza na obszarze miejskim,

- stworzenie nowych miejsc rekreacyjno-wypoczynkowych dla społeczności miejskiej,

- stworzenie siedlisk życia i rozwoju różnego rodzaju organizmów żywych oraz roślin,

- zwiększenie ilości zieleni w mieście,

- zmniejszenie uciążliwości transportowych, takich jak hałas.

W Polsce najbardziej znanym przykładem wykorzystania zielonego dachu jest dach Biblioteki Uniwersyteckiej w Warszawie o powierzchni 1 ha, z czego $5111 \mathrm{~m}^{2}$ stanowi roślinność. Na wyjątkowość warszawskiego ogrodu składają się dwa poziomy: górny o powierzchni 1,0 ha oraz dolny o powierzchni 1,5 ha, pomiędzy którymi umiejscowiona jest kaskada wodna czyniąca to miejsce jeszcze bardziej relaksującym i naturalnym ze względu na szum wody. Zachwyt wzbudza także zarybiony staw, chętnie odwiedzany przez kaczki. Roślinność skomponowana jest w taki sposób, aby można było ją podziwiać bez względu na porę roku. Górny poziom stanowią głównie pnącza, krzewy iglaste i liściaste oraz małe drzewka. Dodatkowo wprowadzono podział według takich kryteriów jak kolor, zapach czy kształt roślin. Krzewy kwitnące na pomarańczowo oraz żółto stanowią tak zwany ogród złocisty, który usytuowany jest w północnej części zielonego dachu. Dodatkowo krajobraz urozmaicają między innymi pnącza oraz drzewka karagany syberyjskiej (odmiana Pendula).Wschodnią cześć zielonego dachu zajmują różne odmiany wierzby: szwajcarska, całolistna żyłkowata, kosodrzewina, jałowiec odmiany Pfitzera Mint Julep oraz pięciornik krzewiasty o białej barwie kwiatów. Ze względu na kolorystykę roślin ta część zielonego dachu nazywana jest srebrnym ogrodem. Od południa możemy podziwiać ogród karminowy, w którym dominującymi barwami są odcienie różu i czerwieni za sprawą takich roślin, jak: krzewuszka cudowna Foliis Purpureis, powojnik alpejski Francis Rivis oraz rozchodnik okazały. Na kształtowanie krajobrazu zieleni wpływ mają także liczne drewniane konstrukcje oraz tarasy pokryte winoroślami typu Zilga i hor-

7 zielona.infrastruktura.pl, Strategia zielonych dachów miasta Hamburg - wywiad, 2016, http:// zielonainfrastruktura.pl/strategia-zielonych-dachow-miasta-hamburg-wywiad/ [dostęp 20.04.2017].

8 Miasto Jest Nasze, Zielona dachy i ich zalety, 2015, http://miastojestnasze.org/zielone-dachyi-ich-zalety/ [dostęp 20.04.2017]. 
tensją pnącą. Wkomponowanie ścieżek w stworzoną przestrzeń pozwala podziwiać każdy zakątek ogrodu, a także panoramę Warszawy i Wisły. Dodatkową atrakcją dla zwiedzających lub odpoczywających jest możliwość podziwiania wnętrza biblioteki dzięki dużym oknom oraz szklanej konstrukcji dachu .

Fragment ogrodu na dachu Biblioteki Uniwersytetu Warszawskiego przedstawia ilustracja 6.

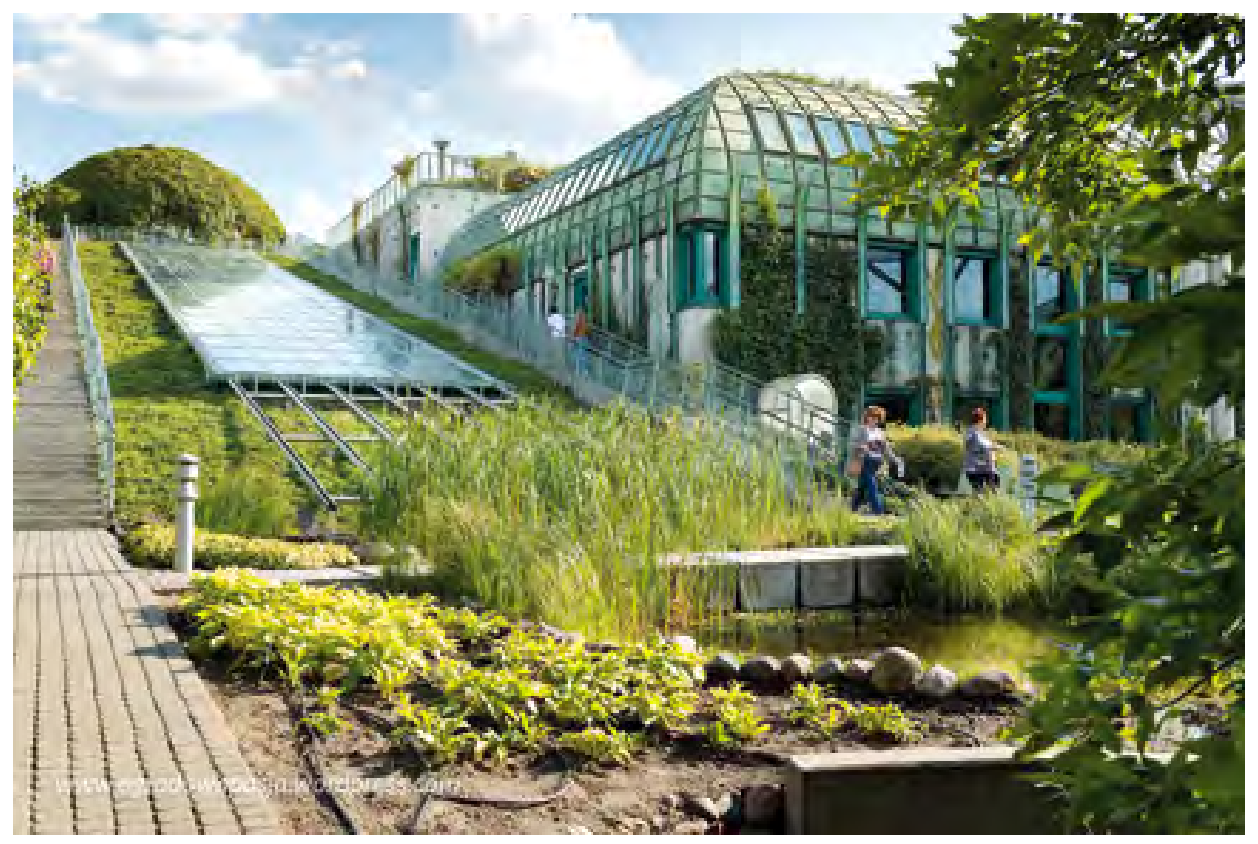

Ilustracja 6. Ogród na dachu Biblioteki Uniwersytetu Warszawskiego Źródło: http://www.dachy.info.pl/branza/dach-dzisiaj-i-jutro/ [dostęp 20.04.2017].

Wpasowywanie zieleni w architekturę obszarów wysoko zurbanizowanych jest popularne na całym świecie ze względu na zwiększenie walorów estetycznych miast oraz daleko idące korzyści. Coraz większa świadomość konieczności ochrony środowiska naturalnego oraz postęp naukowy w dziedzinie inżynierii budownictwa stwarzają nowe możliwości odbudowy szaty roślinnej. Przykładem wykorzystania nauki do umiejscowienia zieleni w centrum miasta jest znajdujący się w mieście Fukuoka w Japonii budynek o nazwie ACROS Fukuoka Prefectural International Hall pokazany na ilustracji 7.

9 Biblioteka Uniwersytetu Warszawskiego, Ogród, http://www.buw.uw.edu.pl/index.php?option=com_content\&task=view\&id=286\&itemid=91 [dostęp 20.04.2017]. 


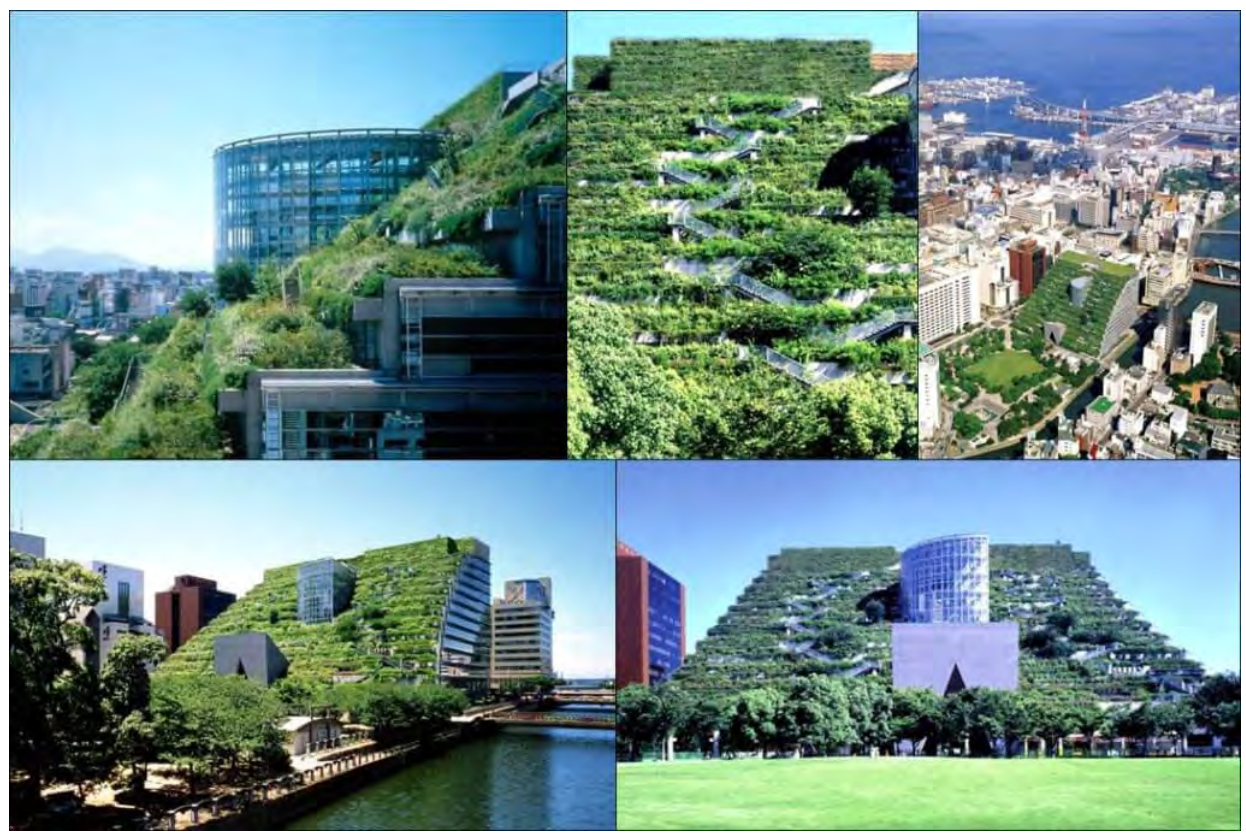

Ilustracja 7. Panorama japońskiego budynku ACROS Fukuoka Prefectural International Hall

Źródło: T. Justin, (2007), Amazing Green Building: The ACROS Fukuoka, https://metaefficient.com/ architecture-and-building/amazing-green-building-the-acros-fukuoka.html [dostęp 20.04.2017].

Jedna strona budynku przypomina wyglądem typowy biurowiec złożony z dużej liczby okien tworzących szklane ściany. Drugą stronę stanowi dach pokryty 35 tys. roślin reprezentujących 76 gatunków (Justin, 2007). Budynek służy jako centrum wymiany międzynarodowej, kulturalnej oraz informacyjnej. Posiada między innymi liczne sale konferencyjne, salę muzyczną, Galerię Sztuki Takumi oraz muzeum. Jego całkowita powierzchnia wynosi $97252 \mathrm{~m}^{2}$, obiekt składa się z 14 kondygnacji nad ziemią i 4 pięter pod ziemią, które pełnią funkcję parkingów ${ }^{10}$.

W niektórych krajach, takich jak Hiszpania czy Stany Zjednoczone, zielone dachy zaczęto stosować na dachach autobusów komunikacji miejskiej, tworząc w ten sposób mobilne ogrody. Dzięki temu podczas upałów możliwe jest zmniejszenie zużycia energii na klimatyzację wnętrza pojazdu. Ponadto mobilne ogrody przyczyniają się do pochłaniania dwutlenku węgla i produkcji tlenu, co korzystnie wpływa na zmniejszenie zanieczyszczenia powietrza (Hernandez, 2012; zielona. infrastruktura.pl, 2015). Przykład mobilnego ogrodu z wykorzystaniem pojazdu przedstawia ilustracja 8 .

10 Greenroofs.com, ACROS Fukuoka Prefectural International Hall, http://www.greenroofs. com/projects/pview.php?id=476 [dostęp 20.04.2017]. 


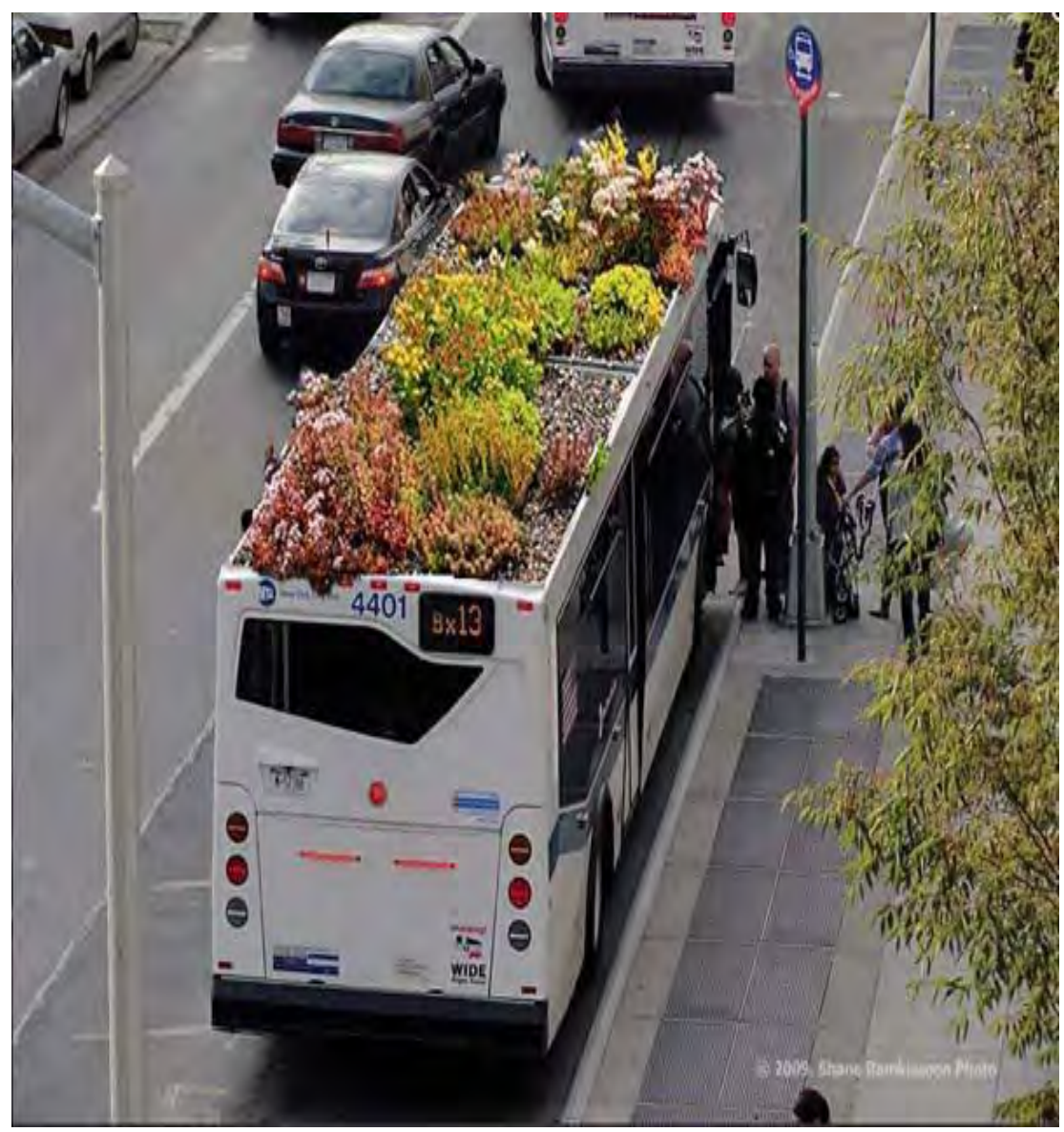

Ilustracja 8. Mobilny zielony dach na autobusie

Źródto: P. Hernandez, 2012.

Rozwiązanie podobne do zielonych dachów stanowią żyjące ściany, ich nazwa pochodzi od roślinności, którą ściana jest porośnięta. Pionowe ogrody doskonale sprawdzają się jako bariera chroniąca przed hałasem oraz pochłaniająca zanieczyszczenia generowane przez pojazdy. Nowatorskie rozwiązanie zostało wprowadzone między innymi w Poznaniu przez market Leroy Merlin. Żyjąca ściana stanowi wyjście na zewnątrz terenu handlowego, gdzie znajduje się dział z produktami ogrodowymi. Nawadnianie oraz dostarczanie roślinom odpowiedniej ilości nawozów odbywa się w sposób całkowicie zautomatyzowany. Nadmiar wody opadowej zbierany jest natomiast do specjalnie skonstruowanych koryt. Do pokrycia ściany budynku wykorzystano głównie rośliny zimozielone, jak na przykład runianka i rozchodnik. W odróżnieniu od zielonych 
dachów żyjące ściany wymagają większych zabiegów pielęgnacyjnych, które polegają na przycinaniu roślin, wycinaniu chwastów, roślin samosiejek oraz dostarczeniu odpowiedniej ilości nawozów. Dodatkowo konieczne jest czyszczenie systemu nawadniania ${ }^{11}$. Projekt żywej ściany wdrożony przez market Leroy Merlin przedstawia ilustracja 9.

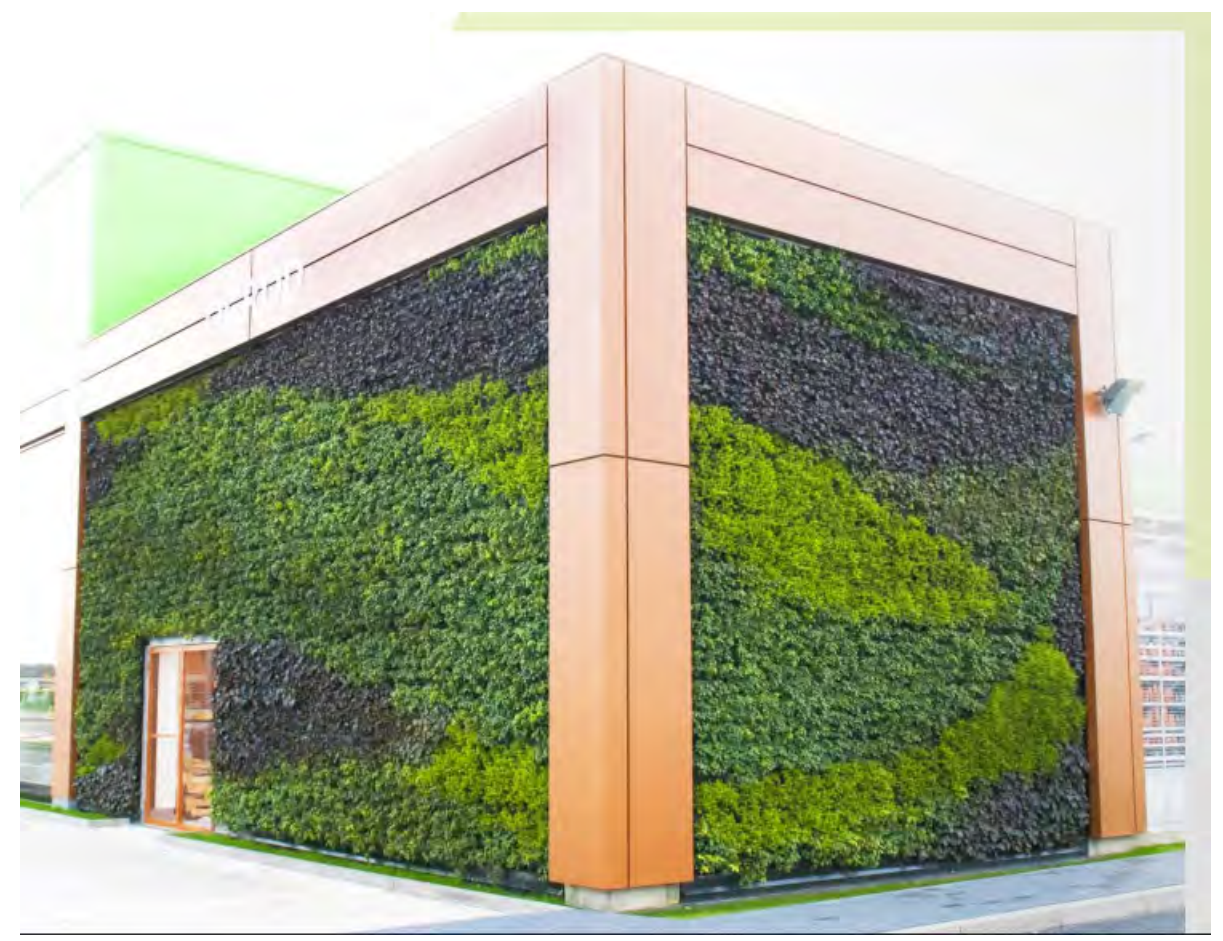

Ilustracja 9. Żywa ściana w Poznaniu

Źródło: D. Skarżyński, Żyjace ściany - przegląd inwestycji zrealizowanych w Polsce, Garden over the head, fot. Witold Harbacewicz, http://psdz.pl/publikacje/ZIELONE\%20DACHY\%20 I\%20ZYJACE\%20SCIANY\%20-\%20SYSTEMOWE\%20ROZWIAZANIA\%201\%20PRZEGLAD\%20 INWESTYCJI\%20W\%20POLSKICH\%20GMINACH.pdf [dostęp 20.04.2017].

Zielone dachy oraz żyjące ściany pozwalają zamienić szary krajobraz w przestrzeń zieloną, bardziej przyjazną człowiekowi oraz ptakom i owadom, podnosząc jednocześnie jakość życia społecznego na obszarach zurbanizowanych.

11 D. Skarżyński, Żyjące ściany - przeglqd inwestycji zrealizowanych w Polsce, s. 13-18, http://psdz.pl /publikacje/ZIELONE\%20DACHY\%20I\%20ZYJACE\%20SCIANY\%20-\%20SYSTEMOWE\%20 ROZWIAZANIA\%20I\%20PRZEGLAD\%20INWESTYCJI\%20W\%20POLSKICH\%20GMINACH.pdf [dostęp 20.04.2017]. 


\section{Podsumowanie}

Liczne projekty tworzenia i wykorzystywania małych ekosystemów pokazują, iż takie zagospodarowanie przestrzeni miejskiej cieszy się aprobatą miejscowej społeczności, która zyskuje nowe miejsce wypoczynku oraz rekreacji na „starym” obszarze miasta. Przybywające coraz to nowe obiekty, w których możemy zauważyć rosnącą zieleń, są dowodem na to, że możliwe jest spójne i efektowne połączenie infrastruktury budowlanej z infrastrukturą zieleni. Rozwiązania tego typu przyczyniają się do oszczędności finansowych, promowania ekologicznych rozwiązań, a zarazem pokazują, jakie możliwości daje logistyczne podejście do rozwoju miasta i jego otoczenia.

\section{Bibliografia}

Biblioteka Uniwersytetu Warszawskiego, Ogród, http://www.buw.uw.edu.pl/index.php?optio$\mathrm{n}=$ com_content\&task=view\&id=286\&itemid=91 [dostęp 20.04.2017].

e-czytelnia.abrys.pl, Błękitno-zielona sieć, 2013, http://e-czytelnia.abrys.pl/dodatek-specjalny/2013-9-701/zeszyt-specjalny-8101/blekitno-zielona-siec-16598 [dostęp 20.04.2017].

e-czytelnia.abrys.pl, Zielono-błękitna infrastruktura a retencja krajobrazowa w miastach, 2015, http://e-czytelnia.abrys.pl/wodociagi-kanalizacja/2015-9-868/temat-numeru-10216/ zielono-blekitna-infrastruktura-a-retencja-krajobrazowa-w-miastach-20534 [dostęp 20.04.2017].

EHREK, Ekohydrologiczna rekultywacja zbiorników rekreacyjnych „Arturówek” jako modelowe podejście do rekultywacji zbiorników wodnych, http://www.arturowek.pl/content/wdrozenia [dostęp 20.04.2017].

Gorgoń J., Znaczenie i rola błękitno-zielonej infrastruktury w adaptacji do zmian klimatu, http:// www.ietu.katowice.pl/aktual/Poleko2016/4_Gorgon_J_Znaczenie_i_rola_BZI_w_adaptacji_do_zmian_klimatu_zab.pdf [dostęp 20.04.2017].

Greenroofs.com, ACROS Fukuoka Prefectural International Hall, http://www.greenroofs.com/ projects/pview.php?id=476 [dostęp 20.04.2017].

Hernandez P., Mobilne zielone dachy w mieście, (2012), http://www.architekturakrajobrazu.info/ przestrze-miejska-98994/141-przestrze-miejska/2616-mobilne-zielone-dachy-w-miecie [dostęp 20.04.2017].

HYDROIDEA, Mała retencja wód w miastach. Zbiorniki retencyjne i zbiorniki infiltracyjno-sedymentacyjne, http://www.hydroidea.com/oferta/mala_retencja_wody/ [dostęp 20.04.2017].

Justin T., (2007), Amazing Green Building: The ACROS Fukuoka, https://metaefficient.com/architecture-and-building/amazing-green-building-the-acros-fukuoka.html [dostęp 20.04.2017]. 
Miasto Jest Nasze, Zielone dachy i ich zalety, (2015), http://miastojestnasze.org/zielone-dachy-i-ich-zalety/[dostęp 20.04.2017].

Millennium Ecosystem Assessment, (2005), Ecosystems and human well-being, http://www.millenniumassessment.org/documents/document.356.aspx.pdf.

Singer M., Projekt „Błękitno-Zielona Łódź”, http://www.uni-logistics.uni.lodz.pl/pliki/Artykul_ Singer_Malgorzata_Blekitno-zielona_Lodz.pdf [dostęp 20.04.2017].

Skarżyński D., Żyjące ściany - przegląd inwestycji zrealizowanych w Polsce, s. 13-18, http://psdz. pl/publikacje/ZIELONE\%20DACHY\%20I\%20ZYJACE\%20SCIANY\%20-\%20SYSTEMOWE\%20 ROZWIAZANIA\%20I\%20PRZEGLAD\%20INWESTYCJI\%20W\%20POLSKICH\%20GMINACH.pdf [dostęp 20.04.2017].

urbnews.pl, Miejska wyspa ciepła - jak powstaje ijak jej zaradzić, (2014), http://urbnews.pl/miejska-wyspa-ciepla-powstaje-zaradzic/ [dostęp 20.04.2017].

Wagner I., Krauze K., Jurczak T., Zalewski M., (2015), Zielono-błękitna infrastruktura a retencja krajobrazowa w miastach, http://www.arturowek.pl/userfiles/file/Wagner\%20i\%20in_\%20 2015.pdf [dostęp 20.04.2017].

Wagner I., Krauze K., Zalewski M., (2013), Błękitne aspekty zielonej infrastruktury, https://www. teraz-srodowisko.pl/media/pdf/aktualnosci/1576-Blekitne-aspekty-zielonej-infrastruktury. pdf [dostęp 20.04.2017].

Woźniak T., (2012), Drugie życie łódzkich rzek, http://www.metropolie.pl/wp-content/uploads/2012/08/07-Lodz-praktyka2.pdf [dostęp 20.04.2017].

wymarzony.ogród.pl, Zielone dachy. Sposób na roślinność w mieście i nie tylko, https://www. wymarzonyogrod.pl/zakladanie-ogrodu/pomysly-na-ogrod/zielone-dachy-sposob-naroslinnosc-w-miescie-i-nie-tylko,23_1782.html [dostęp 20.04.2017].

zielona.infrastruktura.pl, Mobilne zielone dachy na autobusach, (2015), http://zielonainfrastruktura.pl/mobilne-dachy-zielone-na-autobusach/[dostęp 20.04.2017].

zielona.infrastruktura.pl, Strategia zielonych dachów miasta Hamburg - wywiad, (2016), http:// zielonainfrastruktura.pl/strategia-zielonych-dachow-miasta-hamburg-wywiad/ [dostęp 20.04.2017].

Zielony-Dach, Dach intensywny, ogrody dachowe, tarasy zielone, https://e-zielonydach.pl/dach-intensywny/[dostęp 20.04.2017].

\section{Źródta internetowe}

http://www.dachy.info.pl/branza/dach-dzisiaj-i-jutro/ [dostęp 20.04.2017].

http://www.obud.pl/art,5933,specjalna-papa-zgrzewalna-do-dachow-zielonych----izolmat-

plan-zielony-dach-pye-pv250-s5,d_dachy [dostęp 20.04.2017]. 